\title{
Change in Work-Related Income Following the Uptake of Treatment for Mental Disorders Among Young Migrant Women in Norway: A National Register Study
}

Kamila Angelika Hynek ( $\sim$ KamilaAngelika.Hynek@fhi.no)

Norwegian Institute of Public Health https://orcid.org/0000-0002-4987-4441

Anna-Clara Hollander

Karolinska Institutet

Aart Liefbroer

Netherlands Interdisciplinary Demographic Institute; University of Groningen; Vrije Universiteit Amsterdam

Lars Johan Hauge

Norwegian Institute of Public Health: Folkehelseinstituttet

Melanie Lindsay Straiton

Norwegian Institute of Public Health: Folkehelseinstituttet

Research article

Keywords: Early adulthood, Income, Mental disorder, Migrant women, Outpatient mental healthcare treatment

Posted Date: March 29th, 2021

DOI: https://doi.org/10.21203/rs.3.rs-122529/v2

License: @ (i) This work is licensed under a Creative Commons Attribution 4.0 International License. Read Full License

Version of Record: A version of this preprint was published at Frontiers in Public Health on January 7th, 2022. See the published version at https://doi.org/10.3389/fpubh.2021.736624. 


\section{Abstract}

Purpose Mental disorders are associated with several work-related outcomes such as loss of income. Not much is known about how this varies with migrant background. This study investigated the change in work-related income following the uptake of outpatient mental healthcare (OPMH) treatment, a proxy for mental disorder, in young women with and without migrant background. Additionally, we looked at how the association varied by income level

Methods Using data from four national registries, the study population consisted of women aged 23-40 years residing in Norway for at least three consecutive years between 2006 and 2013 ( $N=640,527)$. By using a stratified linear regression with individual fixed effects, we investigated differences between majority women, descendants and eight migrant groups. Interaction analysis was conducted in order to examine differences in income loss following the uptake of $\mathrm{OPMH}$ treatment among women with and without migrant background.

Results OPMH treatment was associated with a decrease in income for all groups. However, the negative effect was stronger among those with low income. Only migrant women from EU Eastern Europe with a high income were not significantly affected following OPMH treatment.

Conclusion Experiencing a mental disorder during a critical age for establishment in the labour market may not only affect income but also subsequent workforce participation and dependency on social welfare services, regardless of migrant background, resulting in large economic costs for both the individual and for society as a whole.

\section{Introduction}

Mental disorders are one of the main reasons for labour market marginalization, and are linked to increased unemployment, loss of work-related productivity and income [1,2]. In turn, this can increase dependence on social welfare services, resulting in large economic costs for the whole society [3]. Mental disorders are most prevalent during early adulthood due to the multiple critical changes early adults experience, such as labour-market establishment [4], with women in particular being at risk $[5,6]$.

Furthermore, migrants, especially women, are at increased risk of many, but not all, mental disorders when compared to the majority population [7]. This, however, depends on the country of origin [8]. Yet, migrants use healthcare services to a lesser extent than the non-migrant population, with differences by country of origin and by legal status $[9,10]$. In addition to an increased risk of mental disorders, women have lower employment rates than men [11], and the gender gap in wages in many countries is still large [12]. The gender difference in employment rates is even larger for migrants. Migrant women also have lower income than both non-migrants and migrant men and are overrepresented in lower-skilled jobs [13]. Large differences are however, found by region of origin [14], with non-Western migrants being the most disadvantaged [15,16]. Given the disadvantage migrant women face, both in terms of increased risk of mental disorders and poorer labour market attachment, compared with majority women, we aim to investigate the association between mental disorder and subsequent work-related income with a particular focus on the differences between migrant and non-migrant women.

The association between mental disorders and labour market participation may be due to poor labour market attachment causing mental disorder (causation) or by mental disorder causing adverse work-related outcomes (selection) [17]. There is support for both perspectives and evidence suggests they are not mutually exclusive. In this study, we use longitudinal data to examine the selection perspective, by examining income differences between people who have and who have not been treated for mental health issues. The selection perspective assumes that experiencing a mental disorder can hinder socioeconomic development. Mental disorders during early adulthood can result in difficulties in keeping a job [18], thus influencing labour market participation and income.

Previous studies have found that mental disorders have a negative impact on several work-related outcomes such as poor labour market attachment [19-22] and lower earnings, with an income reduction of between 6.5 and 20.0 percent [23-26]. This loss of income has been explained by reduced productivity or concentration. However, the effect of mental disorders on income varies by type of disorder and across the income distribution. The most adverse effect is seen in the lowest distribution tail [26,23].

Studies focusing on differences between migrants and non-migrants found that mental disorders, defined by use of in- and outpatient mental healthcare services, increase the risk of labour market marginalisation including disability pension, sickness absence and unemployment in both non-migrants and migrants [27-29]. Swedish-born individuals with mental disorders had a higher risk of both disability pension and sickness absence when compared to Western and non-Western migrants, but lower risk of unemployment, especially compared to non-Western migrants [28]. These differences were mainly explained by migrants' poorer previous labour market attachment, with many not qualifying for, or having limited access to, sickness and disability benefits. Furthermore, migrants with common mental disorders had higher levels of long-term unemployment when compared to non-migrants with common mental disorders [29]. Despite the increased focus on the association between mental disorders and work-related outcomes, the focus on differences by gender or migrant background is still limited [30].

If having a mental disorder impacts earning capacity, it is possible that migrant women may face a triple disadvantage due to being a woman, a migrant and having a mental disorder. This makes it interesting to investigate whether the effect of mental disorders on work-related income differs for women with and without migrant background. Furthermore, as previous studies [e.g. 23,26] found the effect of mental disorders on earnings differs depending on the initial income level, we also consider the differences between women in low- and high-income brackets. We hypothesize that migrant women will experience greater loss of income following the treatment for mental disorders when compared to the Norwegian majority and descendant women, regardless of income group. In this study, we use the uptake of outpatient mental healthcare (OPMH) treatment as a proxy for mental disorder.

\section{Methods}


This study is a dynamic national register-based prospective cohort study. We used data from the total resident population of women in Norway. A unique deidentifiable version of a personal identification number (PIN), was used to combine the information from four national registers. PIN is assigned to all Norwegian citizens at birth, as well as to all individuals registered as residents in Norway for at least six months. The Central Population Registry provided demographic information such as birth year, country of origin, migrant background and marital status. The KUHR database contains information on compensation claims from health professionals such as those working in OPMH services. From this we were able to identify individuals with OPMH consultations during the years 2006-2013. Information on the highest obtained education level was extracted from the National Education Database, while the FD-Trygd database provided information on work-related income and child benefits for the years 2006-2013.

\section{Study design and population}

We included women aged 23-40 years, born between 1968 and 1988, who resided in Norway for at least three consecutive years during the study period 20062013. This age group was chosen because by age 23 , the majority of women have completed their education and are entering the labour force. A disruption in this process, such as the onset of a mental disorder, can have both short-term and long-term effects.

All women were followed from the start of the study in 2006, when turning 23 or from the year of migration to Norway. Censoring occurred at the end of the study in 2013, when turning 40 years or the year of emigration or death. Furthermore, we excluded women who had no work-related income throughout the study period $(N=33,755)$, as we were interested in the change in work-related income. The eligible sample consisted of 640,527 women.

\section{Measures}

The outcome variable was work-related income, defined as yearly pre-tax wages and income from self-employment for the years 2006-2013. Income for all years was inflated to 2013 levels by using the Norwegian consumer price index. Negative values were recoded to 0 and values higher than 2,000,000 Norwegian kroners (NOK) were set to 2,000,000 NOK. Furthermore, to ease the interpretation of the results, income was recalculated into percentiles and presented as percentile change in income following the uptake of OPMH treatment.

The main exposure variable was OPMH treatment, used as a proxy for mental disorder. Since the first consultation is mainly used to map whether there is a need for further OPMH follow-up, to be exposed, a woman needed to have at least two consultations within a six-month period. In cases where the two contacts occurred in two consecutive calendar years, the year of exposure was set as the year of first contact with OPMH services. Furthermore, to detect changes in income following the uptake of OPMH treatment, we introduced a washout period where each woman defined as exposed had to have at least two years free of OPMH consultations prior to exposure. This was to increase the probability that the contact detected between 2008 and 2013 was a new, and not an ongoing, case.

Additionally, we considered differences in loss of work-related income following the uptake of OPMH treatment by migrant background. Migrant background was divided into three major groups: majority (Norwegian-born with at least one Norwegian-born parent), descendant (Norwegian-born with two foreign-born parents) and migrant (foreign-born with two foreign-born parents). We divided migrants into eight regions of origin: 1) Nordics, 2) Western Europe, 3) EU Eastern Europe, 4) non-EU Eastern Europe, 5) Middle East and North Africa (MENA), 6) Sub-Saharan Africa, 7) South Asia, and 8) East/ South East Asia. Women from countries not fitting into the categories presented above $(\mathrm{N}=9220)$ were excluded from the study sample. The Norwegian majority group was used as a reference group in all analyses.

Covariates included age, education level, marital status and motherhood, all time variant. Age was measured as a continuous variable with values between 23 and 40. Education level was a categorical variable with categories 1) compulsory or lower, 2) upper-secondary, 3) tertiary, and 4) unknown. Marital status was also a categorical variable with values 1) unmarried, 2) married/partner, and 3) previously married. Motherhood (yes/no) was based on whether the woman was receiving child benefit or not, commonly entitled to mothers with a dependent child below the age of 18 [31]. We also controlled for the year of observation to adjust for time fixed effects, with a dummy variable for each year.

\section{Statistical Analysis}

To investigate the effect of OPMH treatment on work-related income, we applied a linear regression model with individual fixed effects. Use of fixed effects models provides a method of assessing the association between exposure (OPMH treatment) and outcome (income), adjusting for all measured time-varying and both measured and unmeasured time-invariant factors within an individual, eliminating confounding from such factors [32]. Each woman is treated as her own control [33]. A disadvantage of using a fixed effects model is that coefficients for time-invariant variables, such as for migrant background, are not estimated [32]. However, by including an interaction term between OPMH treatment (time-variant) and migrant background (time-invariant), the fixed effects models provide coefficients for the interaction between these two variables. Due to a large difference in income between the investigated migrant groups, the analysis was stratified into low- (the bottom third of the income distribution) and high- (the top two thirds of the income distribution) income levels, based on mean work-related income during the years in the study. This distribution divide was chosen to ensure there was a sufficient number of individuals in each group. The regression analyses had a hierarchical set-up with adjustment for age and an interaction term between OPMH treatment and migrant background in Model 1 and educational level (coefficient for the individuals with unknown education were omitted from the analysis), marital status, motherhood and time fixed effects in Model 2. Results for time fixed effects are not shown. Stata 15.0 was used to perform all analyses.

\section{Ethics}

Approval for the use and linkage of data, and the conduction of the study was granted by the Regional Committee for Medical and Health Research Ethics, South East Norway (REK 2014/1970) and the owners of the different registries. Since this study uses already existing administrative data consent to participate was not required. 


\section{Results}

Table 1 shows the characteristics of the study sample, presented by migrant background. All measures, with the exception of income, are presented for the last year in the study. The study sample consisted of $83.2 \%$ majority women, $0.8 \%$ descendant women and $16.0 \%$ migrant women. For a detailed distribution of migrant women by region of origin, see Table 1. OPMH treatment was most common among migrant women from MENA with $8.7 \%$, and least common in EU Eastern European and East/ South-East Asian women (2.3\% and 2.2\% respectively). Migrant women in general had a lower work-related income, both mean and median, compared to majority and descendant women, though there were large differences by region of origin. Women from the MENA and from SubSaharan Africa had the lowest, while women from the Nordics and from Western Europe had the highest work-related income. For other characteristics of the study sample see Table 1. 
Table 1

Characteristics of the study sample, by migrant background.

\begin{tabular}{|c|c|c|c|c|c|c|c|c|c|c|c|c|}
\hline & \multirow[t]{2}{*}{ Total } & \multicolumn{3}{|c|}{ Migrant background: } & \multicolumn{8}{|c|}{ Region of origin: } \\
\hline & & Majority & Descendant & Migrant & Nordics & $\begin{array}{l}\text { Western } \\
\text { Europe }\end{array}$ & $\begin{array}{l}\text { EU } \\
\text { Eastern } \\
\text { Europe }\end{array}$ & $\begin{array}{l}\text { Non-EU } \\
\text { Eastern } \\
\text { Europe }\end{array}$ & $\begin{array}{l}\text { Middle } \\
\text { East } \\
\text { and } \\
\text { North } \\
\text { Africa }\end{array}$ & $\begin{array}{l}\text { Sub- } \\
\text { Saharan } \\
\text { Africa }\end{array}$ & $\begin{array}{l}\text { South } \\
\text { Asia }\end{array}$ & $\begin{array}{l}\text { Ea } \\
\text { So } \\
\text { Ea } \\
\text { As }\end{array}$ \\
\hline $\begin{array}{l}\text { Number of } \\
\text { observations }\end{array}$ & $4,044,019$ & $3,363,342$ & 33,398 & 647,279 & 77,189 & 53,516 & 130,552 & 75,863 & 68,945 & 59,412 & 55,017 & 12 \\
\hline $\begin{array}{l}\text { Number of } \\
\text { individuals }\end{array}$ & 640,527 & 522,731 & 5,324 & 112,472 & 13,867 & 9,717 & 24,948 & 12,336 & 10,911 & 9,943 & 8,774 & 21 \\
\hline$\%$ of the population & & 83.2 & 0.8 & 16.0 & 2.1 & 2.0 & 4.0 & 2.0 & 2.1 & 2.1 & 1.7 & 3.8 \\
\hline$\%$ of migrants & - & - & - & - & 12.3 & 8.6 & 22.2 & 11.0 & 9.7 & 8.8 & 7.8 & 19 \\
\hline $\begin{array}{l}\text { Years in study, } \\
\text { mean (sd) }\end{array}$ & $6.3(1.9)$ & $6.4(1.8)$ & $6.3(1.9)$ & $\begin{array}{l}5.8 \\
(1.9)\end{array}$ & $\begin{array}{l}5.6 \\
(2.0)\end{array}$ & $\begin{array}{l}5.5 \\
(1.8)\end{array}$ & $\begin{array}{l}5.2 \\
(1.8)\end{array}$ & $\begin{array}{l}6.1 \\
(1.9)\end{array}$ & $\begin{array}{l}6.3 \\
(1.8)\end{array}$ & $6.0(1.8)$ & $\begin{array}{l}6.3 \\
(1.8)\end{array}$ & $\begin{array}{l}5.8 \\
(1 .\end{array}$ \\
\hline Age, mean (sd) & $34.5(5.1)$ & $34.7(5.1)$ & $30.7(4.5)$ & $\begin{array}{l}33.7 \\
(4.8)\end{array}$ & $\begin{array}{l}33.5 \\
(5.1)\end{array}$ & $\begin{array}{l}34.7 \\
(4.6)\end{array}$ & $\begin{array}{l}32.7 \\
(4.6)\end{array}$ & $\begin{array}{l}33.9 \\
(4.9)\end{array}$ & $\begin{array}{l}34.0 \\
(4.9)\end{array}$ & $\begin{array}{l}33.8 \\
(4.8)\end{array}$ & $\begin{array}{l}34.2 \\
(4.9)\end{array}$ & $\begin{array}{l}34 \\
(4 .\end{array}$ \\
\hline \multicolumn{13}{|l|}{ OPMH service use } \\
\hline Yes, N (\%) & $\begin{array}{l}39,605 \\
(6.2)\end{array}$ & $\begin{array}{l}34,615 \\
(6.6)\end{array}$ & $333(6.7)$ & $\begin{array}{l}4,657 \\
(4.1)\end{array}$ & $\begin{array}{l}762 \\
(5.5)\end{array}$ & $\begin{array}{l}415 \\
(4.3)\end{array}$ & $\begin{array}{l}575 \\
(2.3)\end{array}$ & $\begin{array}{l}654 \\
(5.3)\end{array}$ & $\begin{array}{l}952 \\
(8.7)\end{array}$ & $\begin{array}{l}370 \\
(3.7)\end{array}$ & $\begin{array}{l}448 \\
(5.1)\end{array}$ & $\begin{array}{l}48 \\
(2 .\end{array}$ \\
\hline No, N (\%) & $\begin{array}{l}600,922 \\
(93.8)\end{array}$ & $\begin{array}{l}488,116 \\
(93.4)\end{array}$ & $\begin{array}{l}4,991 \\
(93.3)\end{array}$ & $\begin{array}{l}107,815 \\
(95.9)\end{array}$ & $\begin{array}{l}13,105 \\
(94.5)\end{array}$ & $\begin{array}{l}9,302 \\
(95.7)\end{array}$ & $\begin{array}{l}24,373 \\
(97.7)\end{array}$ & $\begin{array}{l}11,682 \\
(94.7)\end{array}$ & $\begin{array}{l}9,959 \\
(91.3)\end{array}$ & $\begin{array}{l}9,573 \\
(96.3)\end{array}$ & $\begin{array}{l}8,326 \\
(94.9)\end{array}$ & $\begin{array}{l}21 \\
(9\end{array}$ \\
\hline $\begin{array}{l}\text { Personal income } \\
\text { (percentiles), mean } \\
(\text { sd })^{1}\end{array}$ & $\begin{array}{l}50.4 \\
(29.2)\end{array}$ & $\begin{array}{l}53.0 \\
(28.4)\end{array}$ & $45.5(30.4)$ & $\begin{array}{l}37.2 \\
(29.6)\end{array}$ & $\begin{array}{l}51.7 \\
(30.8)\end{array}$ & $\begin{array}{l}48.7 \\
(32.9)\end{array}$ & $\begin{array}{l}37.2 \\
(27.1)\end{array}$ & $\begin{array}{l}40.0 \\
(29.9)\end{array}$ & $\begin{array}{l}29.9 \\
(27.7)\end{array}$ & $\begin{array}{l}27.2 \\
(26.2)\end{array}$ & $\begin{array}{l}32.1 \\
(28.7)\end{array}$ & $\begin{array}{l}33 \\
(2\end{array}$ \\
\hline $\begin{array}{l}\text { Personal income } \\
\text { (percentiles), } \\
\text { Median }^{1}\end{array}$ & 51 & 54 & 43 & 32 & 52 & 46 & 33 & 35 & 23 & 19 & 25 & 27 \\
\hline \multicolumn{13}{|l|}{ Income group (\%) ${ }^{1}$} \\
\hline Low & 33.3 & 28.6 & 41.8 & 57.3 & 34.6 & 40.4 & 57.2 & 52.5 & 69.8 & 73.8 & 65.5 & 63 \\
\hline High & 66.7 & 71.4 & 58.2 & 42.7 & 65.4 & 59.6 & 42.8 & 47.5 & 30.3 & 26.2 & 34.5 & 36 \\
\hline \multicolumn{13}{|l|}{ Educational level } \\
\hline $\begin{array}{l}\text { Compulsory or } \\
\text { lower, N (\%) }\end{array}$ & $\begin{array}{l}90,570 \\
(14.1)\end{array}$ & $\begin{array}{l}65,641 \\
(12.6)\end{array}$ & $970(18.2)$ & $\begin{array}{l}23,959 \\
(21.3)\end{array}$ & $\begin{array}{l}842 \\
(6.1)\end{array}$ & $\begin{array}{l}752 \\
(7.7)\end{array}$ & $\begin{array}{l}2,187 \\
(8.8)\end{array}$ & $\begin{array}{l}2,457 \\
(19.9)\end{array}$ & $\begin{array}{l}4,072 \\
(37.3)\end{array}$ & $\begin{array}{l}4,338 \\
(43.6)\end{array}$ & $\begin{array}{l}3,122 \\
(35.6)\end{array}$ & $\begin{array}{l}6,1 \\
(28\end{array}$ \\
\hline $\begin{array}{l}\text { Upper-secondary, N } \\
(\%)\end{array}$ & $\begin{array}{l}195,626 \\
(30.5)\end{array}$ & $\begin{array}{l}169,884 \\
(32.5)\end{array}$ & $\begin{array}{l}1,588 \\
(29.8)\end{array}$ & $\begin{array}{l}24,154 \\
(21.5)\end{array}$ & $\begin{array}{l}3,538 \\
(25.5)\end{array}$ & $\begin{array}{l}1,250 \\
(12.9)\end{array}$ & $\begin{array}{l}5,851 \\
(23.5)\end{array}$ & $\begin{array}{l}2,906 \\
(23.6)\end{array}$ & $\begin{array}{l}2,339 \\
(21.4)\end{array}$ & $\begin{array}{l}2,179 \\
(21.9)\end{array}$ & $\begin{array}{l}1,852 \\
(21.1)\end{array}$ & $\begin{array}{l}4,2 \\
(1 !\end{array}$ \\
\hline Tertiary, N (\%) & $\begin{array}{l}333,383 \\
(52.1)\end{array}$ & $\begin{array}{l}286,553 \\
(54.8)\end{array}$ & $\begin{array}{l}2,693 \\
(50.6)\end{array}$ & $\begin{array}{l}44,137 \\
(39.2)\end{array}$ & $\begin{array}{l}6,528 \\
(47.1)\end{array}$ & $\begin{array}{l}5,893 \\
(60.7)\end{array}$ & $\begin{array}{l}11,002 \\
(44.1)\end{array}$ & $\begin{array}{l}5,825 \\
(47.2)\end{array}$ & $\begin{array}{l}3,044 \\
(27.9)\end{array}$ & $\begin{array}{l}2,197 \\
(22.1)\end{array}$ & $\begin{array}{l}2,428 \\
(27.7)\end{array}$ & $\begin{array}{l}7,2 \\
(3:\end{array}$ \\
\hline Unknown, N (\%) & $\begin{array}{l}20,948 \\
(3.3)\end{array}$ & $653(0.1)$ & $73(1.4)$ & $\begin{array}{l}20,222 \\
(18.0)\end{array}$ & $\begin{array}{l}2,959 \\
(21.3)\end{array}$ & $\begin{array}{l}1,822 \\
(18.8)\end{array}$ & $\begin{array}{l}5,908 \\
(23.7)\end{array}$ & $\begin{array}{l}1,148 \\
(9.3)\end{array}$ & $\begin{array}{l}1,456 \\
(13.3)\end{array}$ & $\begin{array}{l}1,229 \\
(12.4)\end{array}$ & $\begin{array}{l}1,372 \\
(15.6)\end{array}$ & $\begin{array}{l}4,3 \\
(1 !\end{array}$ \\
\hline \multicolumn{13}{|l|}{ Marital status } \\
\hline Unmarried, N (\%) & $\begin{array}{l}323,649 \\
(50.5)\end{array}$ & $\begin{array}{l}284,042 \\
(54.3)\end{array}$ & $\begin{array}{l}2,551 \\
(47.9)\end{array}$ & $\begin{array}{l}37,056 \\
(32.9)\end{array}$ & $\begin{array}{l}8,755 \\
(63.1)\end{array}$ & $\begin{array}{l}4,819 \\
(49.6)\end{array}$ & $\begin{array}{l}8,891 \\
(35.6)\end{array}$ & $\begin{array}{l}2,953 \\
(23.9)\end{array}$ & $\begin{array}{l}1,851 \\
(17.0)\end{array}$ & $\begin{array}{l}3,381 \\
(34.0)\end{array}$ & $\begin{array}{l}964 \\
(11.0)\end{array}$ & $\begin{array}{l}5,4 \\
(2\end{array}$ \\
\hline $\begin{array}{l}\text { Married/cohabiting, } \\
\text { N (\%) }\end{array}$ & $\begin{array}{l}266,481 \\
(41.6)\end{array}$ & $\begin{array}{l}200,598 \\
(38.4)\end{array}$ & $\begin{array}{l}2,395 \\
(45.0)\end{array}$ & $\begin{array}{l}63,488 \\
(56.5)\end{array}$ & $\begin{array}{l}4,503 \\
(32.5)\end{array}$ & $\begin{array}{l}4,446 \\
(45.8)\end{array}$ & $\begin{array}{l}14,140 \\
(56.7)\end{array}$ & $\begin{array}{l}7,818 \\
(63.4)\end{array}$ & $\begin{array}{l}7,452 \\
(68.3)\end{array}$ & $\begin{array}{l}4,470 \\
(45.0)\end{array}$ & $\begin{array}{l}7,020 \\
(80.0)\end{array}$ & $\begin{array}{l}13 \\
(6:\end{array}$ \\
\hline $\begin{array}{l}\text { Previously married, } \\
\mathrm{N}(\%)\end{array}$ & $\begin{array}{l}50,397 \\
(7.9)\end{array}$ & $\begin{array}{l}38,091 \\
(7.3)\end{array}$ & $378(7.1)$ & $\begin{array}{l}11,928 \\
(10.6)\end{array}$ & $\begin{array}{l}609 \\
(4.4)\end{array}$ & $\begin{array}{l}452 \\
(4.7)\end{array}$ & $\begin{array}{l}1,917 \\
(7.7)\end{array}$ & $\begin{array}{l}1,565 \\
(12.7)\end{array}$ & $\begin{array}{l}1,608 \\
(14.7)\end{array}$ & $\begin{array}{l}2,092 \\
(21.0)\end{array}$ & $\begin{array}{l}790 \\
(9.0)\end{array}$ & $\begin{array}{l}2, \varepsilon \\
(1:\end{array}$ \\
\hline \multicolumn{13}{|l|}{ Motherhood } \\
\hline Yes, N (\%) & $\begin{array}{l}447,017 \\
(30.2)\end{array}$ & $\begin{array}{l}375,314 \\
(71.8)\end{array}$ & $\begin{array}{l}2,675 \\
(50.2)\end{array}$ & $\begin{array}{l}69,028 \\
(61.4)\end{array}$ & $\begin{array}{l}7,736 \\
(55.8)\end{array}$ & $\begin{array}{l}5,183 \\
(53.3)\end{array}$ & $\begin{array}{l}13,151 \\
(52.7)\end{array}$ & $\begin{array}{l}8,481 \\
(68.8)\end{array}$ & $\begin{array}{l}8,179 \\
(75.0)\end{array}$ & $\begin{array}{l}6,806 \\
(68.5)\end{array}$ & $\begin{array}{l}6,832 \\
(77.9)\end{array}$ & $\begin{array}{l}12 \\
(5\end{array}$ \\
\hline No, N (\%) & $\begin{array}{l}193,510 \\
(69.8)\end{array}$ & $\begin{array}{l}147,417 \\
(28.2)\end{array}$ & $\begin{array}{l}2,649 \\
(49.8)\end{array}$ & $\begin{array}{l}43,444 \\
(38.6)\end{array}$ & $\begin{array}{l}6,131 \\
(44.2)\end{array}$ & $\begin{array}{l}4,534 \\
(46.7)\end{array}$ & $\begin{array}{l}11,797 \\
(47.3)\end{array}$ & $\begin{array}{l}3,855 \\
(31.3)\end{array}$ & $\begin{array}{l}2,732 \\
(25.0)\end{array}$ & $\begin{array}{l}3,137 \\
(31.5)\end{array}$ & $\begin{array}{l}1,942 \\
(22.1)\end{array}$ & $\begin{array}{l}9,3 \\
(4:\end{array}$ \\
\hline
\end{tabular}

All measurements are for the last year individuals are observed in the dataset. ${ }^{1}$ Except of income and income distribution which are means and medians for i year's individuals are contributing in the study. 
Fig. 1 presents the age-adjusted mean income in percentiles, by migrant background for women with OPMH treatment, between four years prior to, and three years after, the uptake of treatment. Low- and high-income levels are represented in the figure separately. For most groups, income flattened a year before treatment, especially among those with low income. For women in the high-income group, income tended to increase again two years after the uptake of treatment, while for women in the low-income group, it seemed to remain stable in the years following the uptake of treatment.

In order to investigate the effect of OPMH treatment on subsequent work-related income, we applied linear regression with individual fixed effects. The analysis was stratified by low- and high-income (Table 2). Results from Model 1, for both income levels, show that OPMH treatment is associated with a decrease in income when compared to non-users. Adjustment for several covariates (Model 2) did not change the effect of OPMH treatment on the main outcome. We found that OPMH treatment had a greater adverse effect for those with low income compared to those with high income.

To investigate whether the impact of OPMH treatment on work-related income differed for the Norwegian majority, descendants and migrants, an interaction term between OPMH treatment and migrant background was introduced into the models. In the low-income group, the results in the fully adjusted model (Model 2), show that most migrant groups experience a significantly less adverse, though still negative, effect of OPMH treatment, a proxy for mental disorders, on work-related income when compared to majority women. The effect among women from South Asia, however, was not significantly different from the reference group of majority women. Another exception were women from non-EU Eastern Europe and descendant women, who had -1.6 percentile and -2.5 percentile of additional loss in income when compared to majority women. In the high-income group, only women from Western Europe and EU Eastern Europe were significantly less affected following the uptake of OPMH treatment when compared to majority women. Migrant women from MENA experienced an additional loss in income when compared to the majority. Despite the greater loss of income among women from Nordic countries, SubSaharan Africa, South Asia and East/South East Asia, and a smaller loss of income among women from non-EU Eastern Europe, none of these groups differed significantly from the majority women.

Table 2

Linear fixed-effects model for the change in income ${ }^{1}$ following the uptake of OPMH treatment ${ }^{2}$.

\begin{tabular}{|c|c|c|c|c|c|c|c|c|c|c|c|c|}
\hline \multirow[b]{4}{*}{ OPMH SERVICE USE (REF. NON-USERS) } & \multicolumn{6}{|c|}{ Low income group } & \multicolumn{6}{|c|}{ high income Gorup } \\
\hline & \multicolumn{3}{|c|}{ Model 1} & \multicolumn{3}{|c|}{ Model 2} & \multicolumn{3}{|c|}{ Model 1} & \multicolumn{3}{|c|}{ Model 2} \\
\hline & \multirow{2}{*}{$\begin{array}{l}\boldsymbol{\beta} \\
-9.2\end{array}$} & \multicolumn{2}{|c|}{$95 \% \mathrm{Cl}$} & \multirow{2}{*}{$\begin{array}{l}\boldsymbol{\beta} \\
-9.0\end{array}$} & \multicolumn{2}{|c|}{$95 \% \mathrm{Cl}$} & \multirow{2}{*}{$\begin{array}{l}\boldsymbol{\beta} \\
-5.3\end{array}$} & \multicolumn{2}{|c|}{$95 \% \mathrm{Cl}$} & \multirow{2}{*}{$\begin{array}{l}\boldsymbol{\beta} \\
-5.3\end{array}$} & \multicolumn{2}{|c|}{$95 \% \mathrm{Cl}$} \\
\hline & & -9.4 & -9.0 & & -9.2 & -8.8 & & -5.5 & -5.1 & & -5.5 & -5.1 \\
\hline \multicolumn{13}{|c|}{$\begin{array}{l}\text { INTERACTION BETWEEN OPMH SERVICE USE AND MIGRANT } \\
\text { BACKGROUND (REF. MAJORITY) }\end{array}$} \\
\hline DESCENDANT & -2.1 & -4.1 & -0.1 & -2.5 & -4.4 & -0.5 & -2.2 & -4.3 & -0.2 & -1.9 & -3.9 & 0.1 \\
\hline \multicolumn{13}{|l|}{ MIGRANTS: } \\
\hline NORDICS & 2.0 & 0.6 & 3.4 & 2.0 & 0.6 & 3.4 & -2.2 & -3.6 & -0.9 & -1.1 & -2.5 & 0.2 \\
\hline WESTERN EUROPE & 3.4 & 1.4 & 5.4 & 3.3 & 1.4 & 5.3 & 3.0 & 1.2 & 4.7 & 4.3 & 2.6 & 6.0 \\
\hline EU EASTERN EUROPE & 3.9 & 2.4 & 5.4 & 3.7 & 2.6 & 5.2 & 5.4 & 3.7 & 7.1 & 6.2 & 4.5 & 7.8 \\
\hline NON-EU EASTERN EUROPE & -2.0 & -3.3 & -0.7 & -1.6 & -2.9 & -0.3 & 0.8 & -0.8 & 2.5 & 1.2 & -0.5 & 2.8 \\
\hline MIDDLE EAST AND NORTH AFRICA & 1.2 & 0.2 & 2.2 & 1.6 & 0.6 & 2.6 & -3.4 & -4.9 & -1.8 & -3.7 & -5.3 & -2.2 \\
\hline SUB-SAHARAN AFRICA & 1.9 & 0.4 & 3.5 & 2.1 & 0.6 & 3.7 & 0.3 & -2.3 & 3.0 & -0.2 & -2.8 & 2.4 \\
\hline SOUTH ASIA & 0.8 & -0.6 & 2.3 & 1.3 & -0.1 & 2.8 & -2.6 & -4.9 & -0.2 & -2.3 & -4.5 & 0.03 \\
\hline EAST/ SOUTH EAST ASIA & 2.4 & 0.9 & 3.9 & 2.6 & 1.1 & 4.1 & -0.01 & -2.1 & 2.0 & -0.2 & -2.2 & 1.9 \\
\hline AGE & 1.9 & 1.9 & 2.0 & 2.0 & 2.0 & 2.0 & 3.8 & 3.7 & 3.8 & 4.1 & 4.1 & 4.1 \\
\hline \multicolumn{13}{|c|}{ EDUCATION (REF. COMPULSORY OR LOWER) } \\
\hline UPPER-SECONDARY & & & & 2.5 & 2.2 & 2.8 & & & & 2.9 & 2.5 & 3.2 \\
\hline TERTIARY & & & & 8.0 & 7.6 & 8.3 & & & & 19.6 & 19.2 & 20.0 \\
\hline MOTHERHOOD (REF. NO) & & & & -1.1 & -1.3 & -1.0 & & & & -7.9 & -8.0 & -7.8 \\
\hline \multicolumn{13}{|l|}{ MARITAL STATUS (REF. UNMARRIED) } \\
\hline MARRIED/COHABITING & & & & 1.4 & 1.2 & 1.5 & & & & 0.6 & 0.5 & 0.8 \\
\hline PREVIOUSLY MARRIED & & & & -0.7 & -0.9 & -0.4 & & & & 1.1 & 0.9 & 1.3 \\
\hline WITHIN R2 & 0.06 & & & 0.08 & & & 0.22 & & & 0.24 & & \\
\hline \multicolumn{13}{|c|}{1 in percentiles; ${ }^{2}$ for low- and high-income groups; coefficients $(\beta)$ with $95 \%$ confidence intervals $(95 \% \mathrm{Cl})$} \\
\hline
\end{tabular}


Fig. 2 is a graphical presentation of the results from Table 2, showing the adjusted effects of OPMH treatment on income by migrant background (on the $x$ axis) and income group. The y-axis shows the percentile loss of income. For most groups, the effect is most adverse in the low-income group, except for women from MENA. Furthermore, the change in income was negative for all groups, except for EU Eastern European women with high income, who did not experience a significant change in income following the uptake of OPMH treatment.

\section{Discussion}

By using longitudinal data, this study explored the changes in income following the uptake of OPMH treatment, a proxy for mental disorder, by migrant background and income level among women aged 23-40 years in Norway. To the best of our knowledge, this is the first study to examine the effect of OPMH treatment on income in migrant-, descendant- and majority women. We found that OPMH treatment had a significantly negative impact on work-related income, which supports the social selection perspective. Adjustment for several time-varying background variables such as educational level, marital status and motherhood did not alter this. Our results are in accordance with previous research showing that mental disorders are associated with subsequent income loss [23-26]. Furthermore, we also found the effect of mental disorders, defined by OPMH treatment, to vary by income level, with greater adverse effects among women in the low-income group. This finding confirms previous research $[23,26]$. However, our hypothesis regarding a greater loss of income among migrant women, when compared to majority and descendant women, was mostly rejected. We found that the change in income following the uptake of OPMH treatment was negative for all groups, except for EU Eastern European women in the high-income group who did not actually experienced a significant change in income. Only descendant and migrant women from non-EU Eastern Europe with low income, and women from MENA with high income, experienced a greater loss of income when compared to majority women. All the other groups either did not differ significantly from majority women or experienced a smaller loss in income following the uptake of OPMH treatment. When accounting for several background variables, only a minor part of the income loss following the uptake of OPMH treatment was explained. However, education level, motherhood and marital status explained the difference in income loss between majority and descendant women and migrant women from Nordic countries and South Asia with a high income.

Despite the higher likelihood of migrant women being in precarious employment and low-skilled jobs than majority population [13], mental disorders seem to have a less adverse, though still negative, effect on their income compared to majority women. This may be a result of postponement of help seeking among some migrant women, especially those with low income. A reason for that could be that in order to provide financial support for themselves and their families, migrant women with a low income stay at work while ill, despite reduced productivity. In Norway, the social benefit is calculated based on the income from the last few years prior to becoming ill or injured [35]. Thus, as many migrant women have more precarious labour market attachment, it is possible that the financial compensation that migrants get when they become ill or lose their job is lower than that for the majority group.

Among those with high income, migrant women from the three European groups experienced a smaller income reduction compared to the majority. Women from Western- and EU Eastern Europe, in both income groups, are largely labour migrants [36], who may only have short-term plans of remaining in the country. Thus, their motivation for staying in work despite mental health difficulties can result in a smaller income reduction than for other groups. In addition, these European women may have better protection than some other migrant groups because they are more likely to enter the Norwegian labour market with valuable skills that are in demand. Other migrant- and descendant women with high income experienced a larger income loss due to mental disorders, measured by OPMH treatment, than majority women did. It is possible that because women in these groups are more often in precarious employment (such as short-term contracts) [13], and compared to European migrants, less likely to enter Norway as labour migrants, they are more likely to fall out of the labour market when their work ability and productivity declines. Thus, income in this migrant group may decrease more than for labour migrants or majority women. Helgesson et al. [28] found that labour market marginalization of migrants can mainly be explained by poor labour market attachment of migrants prior to experiencing a mental disorder when compared to non-migrants. The authors found migrants experiencing mental disorders were at increased risk of unemployment.

The type of mental disorder individuals in the studied groups are treated for could also explain some of the differences in income loss. Studies investigating the association between mental disorders and income found for instance, that the effect was stronger for anxiety disorders than for personality disorders or dysthymia [26]. Previous research found migrant women, mainly from low-income countries, had higher levels of common mental disorders such as anxiety [37]. Thus, selection of migrant women with, for instance, anxiety into the high-income group could explain the larger loss of income among non-Western migrant women. However, in this study, we were unable to investigate the differences by the type of mental disorder.

This study has several strengths. Use of a dynamic sample allowed us to follow women entering the study sample later than at the study start in 2006 , due to immigration or reaching the adequate age, and to include women who died or emigrated during the study period as long as they had at least three consecutive years in the study. Furthermore, we only included potentially healthy women, since we applied a two-year wash-out period to ensure that we measured the change in income due to use of such services. However, to access OPMH services, the referral from a general practitioner or psychologist is required and it may take a long time before an appointment is made. Thus, even before entering OPMH treatment, individuals may have been affected by mental disorders for a significant amount of time and their income may have already started to decrease or stagnate by the time we considered them as exposed, as suggested by Fig. 1.

By using information on OPMH treatment from national registers, we rule out any self-reported bias. Migrants might not only participate in surveys to a lesser extent due to language difficulties but also, when participating, give biased answers due to the experienced discrimination and negative perceptions about migrants [38]. However, it is important to bear in mind that many migrants may face linguistic or cultural barriers when seeking healthcare [39]. Therefore, using OPMH treatment as a proxy for mental disorders represents a selected group of individuals. There are several steps that need to be undertaken before entering OPMH services and individuals in OPMH treatment have actively sought help [40]. Thus, migrants in the OPMH treatment group may be among the 
most resourceful. Use of OPMH treatment only detects those who entered the treatment and not all women experiencing mental disorders. We also lack information on those using private healthcare services or inpatient services. However, inpatient treatment accounts for only about five percent of all contacts with mental healthcare services [41]. The operationalization of mental disorder is therefore the main limitation of this study.

Despite this limitation, utilization of a more detailed grouping of migrants is novel with regard to studying this association. Further, use of register data to gain information on income is an advantage due to no missing income data, as all individuals with paid employment in Norway are registered in the database. Self-reported income is a sensitive topic, and often suffers from large numbers of missing values [42].

\section{Conclusion}

In summary, this study improves our understanding of the association between OPMH treatment and subsequent work-related income among migrant and non-migrant women in Norway. We found OPMH treatment resulted in loss of income among women, irrespective of migrant background or initial income level. However, our study also found that the magnitude of income loss was larger for women with low income and varied by migrant background. In our analyses, we controlled for factors such as educational level, marital status and motherhood in addition to time fixed effects. Furthermore, our fixed effects approach controlled for all unmeasured time-invariant confounders. However, even with these controls, the main effect of OPMH treatment on income remained virtually unchanged. Therefore, in this study, the income loss following the uptake of OPMH treatment cannot be explained by sociodemographic factors. Although possible explanations of this relationship have been discussed, more research investigating the mechanisms involved is needed. In order to prevent income loss among women experiencing, and being treated for, mental disorders, contact with healthcare services should be more effective and easier to navigate and employers need to be flexible. Adjusting tasks to the ability of the employee in order for them to remain in a job can be crucial. This may be especially important for migrant women as participation in the labour market is an important indicator of integration and contribution to the society. Many women, during early adulthood, are starting their career and its disruption can strongly influence their future employment trajectories or their long-term dependency on welfare services. This may result in large costs for the whole society.

\section{Declarations}

\section{Ethics approval and consent to participate}

Approval for use and linkage of data, and conduction of the study was granted by the Regional Committee for Medical and Health Research Ethics, South East Norway (REK 2014/1970) and the owners of the different registries. This study uses already existing administrative data, thus consent to participate was not required.

\section{Consent for publication}

Not applicable

\section{Availability of data and materials}

The datasets generated and analysed for the current study are not publicly available for data protection reasons. However, the data that support the findings of this study may be available from Statistics Norway and HELFO if ethical approval is granted.

\section{Competing interests}

The authors declare no conflict of interests.

\section{Funding}

This research was funded by the Research Council of Norway through the 'Women's Health programme'. The funding body had no role in the design of the study, collection, analysis, interpretation of data or in writing the manuscript. ACH's contribution to the article was funded by Hollander/Forte 201600870/Psykiatrisk vård bland utrikesfödda

\section{Authors' contributions}

KAH designed the study, carried out the statistical analysis, interpreted the data and drafted the manuscript under supervision. MS, main supervisor, interpreted the results, contributed critically to the design of the study and to revising the manuscript. ACH and AL contributed critically to the design of the study and to revising the manuscript. $\mathrm{LJH}$, co-supervisor, contributed to the design of the study, prepared the data file and contributed to revising the manuscript. All authors approved the final version of the manuscript.

\section{Acknowledgements}

This research was funded by the Research Council of Norway through the 'Women's Health programme'. The authors would like to thank Dawit Shawel Abebe for his input in the early stages of planning this paper.

\section{References}

1. OECD (2013) Mental Health and Work: Norway. OECD Publishing, Paris. http://dx.doi.org/10.1787/9789264178984-en 
2. Prins R (2013) Sickness Absence and Disability: An International Perspective. In: Loisel P, Anema JR (eds) Handbook of Work Disability: Prevention and Management. Springer New York, New York, NY, pp 267-288. https://doi.org/10.1007/978-1-4614-6214-9_17

3. Corbière M, Negrini A, Dewa CS (2013) Mental Health Problems and Mental Disorders: Linked Determinants to Work Participation and Work Functioning. In: Loisel P, Anema JR (eds) Handbook of Work Disability: Prevention and Management. Springer New York, New York, NY, pp 267-288. https://doi.org/10.1007/978-1-4614-6214-9_17

4. Cohen P (2014) Measurement issues in epidemiology of psychiatric disorders. In: Koenen KC,Rudenstine S,Susser E, Galea S (eds) A Life course approach to mental disorders. Oxford University Press, Oxford, pp 26-34

5. Steel Z, Marnane C, Iranpour C, Chey T, Jackson JW, Patel V, Silove D (2014) The global prevalence of common mental disorders: a systematic review and meta-analysis 1980-2013. International Journal of Epidemiology 43 (2):476-493. https://doi.org/10.1093/ije/dyu038

6. Van de Velde S, Boyd A, Villagut G, Alonso J, Bruffaerts R, De Graaf R, Florescu S, Haro J, Kovess-Masfety V (2018) Gender differences in common mental disorders: a comparison of social risk factors across four European welfare regimes. European Journal of Public Health 29 (3):481-487. https://doi.org/10.1093/eurpub/cky240

7. Delara M (2016) Social determinants of immigrant women's mental health. Advances in Public Health 2016. https://doi.org/10.1155/2016/9730162

8. Gilliver SC, Sundquist J, Li X, Sundquist K (2014) Recent research on the mental health of immigrants to Sweden: a literature review. European Journal of Public Health 24 (suppl_1):72-79. https://doi.org/10.1093/eurpub/cku101

9. Abebe DS, Lien L, Elstad JI (2017) Immigrants' utilization of specialist mental healthcare according to age, country of origin, and migration history: a nation-wide register study in Norway. Social Psychiatry and Psychiatric Epidemiology 52 (6):679-687. https://doi.org/10.1007/s00127-017-1381-1

10. Straiton ML, Corbett K, Hollander A-C, Hauge LJ (2019) Outpatient mental healthcare service use among women with migrant background in Norway: a national register study. BMC Health Services Research 19 (1). https://doi.org/10.1186/s12913-019-4788-4

11. OECD (2020) Employment: Social Protection - Key Indicators. https://stats.oecd.org/index.aspx?queryid=54741\#.

12. OECD (2020) Gender wage gap (indicator). https://data.oecd.org/earnwage/average-wages.htm.

13. OECD/ European Union (2015) Indicators of Immigrant Integration 2015: Settling In. OECD Publishing, Paris/European Union, Brussels. https://doi.org/10.1787/9789264234024-en

14. Statistics Norway (2020) Employment among immigrants, register-based. Employed persons. 4th quarter, by country background, sex, age, contents and year. https://www.ssb.no/en/statbank/table/09837/tableViewLayout1/.

15. Gorodzeisky A, Semyonov M (2017) Labor force participation, unemployment and occupational attainment among immigrants in West European countries. PLoS One 12 (5):e0176856. https://doi.org/10.1371/journal.pone.0176856

16. Vrålstad S, Wiggen KS (2017) Levekår blant innvandrere i Norge 2016 [Life conditions among immigrants in Norway 2016]. Statistics Norway, OsloKongsvinger

17. Thern E, de Munter J, Hemmingsson T, Rasmussen F (2017) Long-term effects of youth unemployment on mental health: does an economic crisis make a difference? Journal of Epidemiology \& Community Health 71 (4):344-349. https://doi.org/10.1136/jech-2016-208012

18. Mossakowski KN (2014) Social Causation and Social Selection. The Wiley Blackwell Encyclopedia of Health, Illness, Behavior, and Society:2154-2160. https://doi.org/10.1002/9781118410868.wbehibs262

19. Clayborne ZM, Varin M, Colman I (2019) Systematic Review and Meta-Analysis: Adolescent Depression and Long-Term Psychosocial Outcomes. Journal of the American Academy of Child \& Adolescent Psychiatry 58 (1):72-79. https://doi.org/10.1016/j.jaac.2018.07.896

20. Chatterji P, Alegria M, Takeuchi D (2011) Psychiatric disorders and labor market outcomes: Evidence from the National Comorbidity Survey-Replication. Journal of Health Economics 30 (5):858-868. https://doi.org/10.1016/j.jhealeco.2011.06.006

21. López-López JA, Kwong ASF, Washbrook E, Pearson RM, Tilling K, Fazel MS, Kidger J, Hammerton G (2020) Trajectories of depressive symptoms and adult educational and employment outcomes. BJPsych Open 6 (1):e6. https://doi.org/10.1192/bjo.2019.90

22. Mojtabai R, Stuart EA, Hwang I, Susukida R, Eaton WW, Sampson N, Kessler RC (2015) Long-term effects of mental disorders on employment in the National Comorbidity Survey ten-year follow-up. Social Psychiatry and Psychiatric Epidemiology 50 (11):1657-1668. https://doi.org/10.1007/s00127-015$1097-z$

23. Evensen M, Lyngstad TH, Melkevik O, Reneflot A, Mykletun A (2017) Adolescent mental health and earnings inequalities in adulthood: evidence from the Young-HUNT Study. Journal of Epidemiology \& Community Health 71 (2):201-206. https://doi.org/10.1136/jech-2015-206939

24. Philipson A, Alaie I, Ssegonja R, Imberg H, Copeland W, Möller M, Hagberg L, Jonsson U (2020) Adolescent depression and subsequent earnings across early to middle adulthood: a 25-year longitudinal cohort study. Epidemiology and Psychiatric Sciences 29:e123.

https://doi.org/10.1017/S2045796020000360

25. Fletcher JM (2013) Adolescent Depression and Adult Labor Market Outcomes. Southern Economic Journal 80 (1):26-49. https://doi.org/10.4284/00384038-2011.193

26. Marcotte DE, Wilcox-Gok V (2003) Estimating Earnings Losses Due to Mental Illness: A Quantile Regression Approach. Journal of Mental Health Policy and Economics 6 (3):123-134

27. Niederkrotenthaler T, Mittendorfer-Rutz E, Saboonchi F, Helgesson M (2020) The role of refugee status and mental disorders regarding subsequent labour market marginalisation: a register study from Sweden. Social Psychiatry and Psychiatric Epidemiology. https://doi.org/10.1007/s00127-020-01842-8

28. Helgesson M, Tinghög P, Niederkrotenthaler T, Saboonchi F, Mittendorfer-Rutz E (2017) Labour-market marginalisation after mental disorders among young natives and immigrants living in Sweden. BMC Public Health 17 (1):593. https://doi.org/10.1186/s12889-017-4504-4 
29. Di Thiene D, Mittendorfer-Rutz E, Rahman S, Wang M, Alexanderson K, Tiihonen J, La Torre G, Helgesson M (2019) Trajectories of sickness absence, disability pension and unemployment in young immigrants with common mental disorders. European Journal of Public Health:1-8.

https://doi.org/10.1093/eurpub/ckz046

30. Reneflot A, Evensen M (2014) Unemployment and psychological distress among young adults in the Nordic countries: A review of the literature. International Journal of Social Welfare 23 (1):3-15. https://doi.org/10.1111/ijsw.12000

31. NAV (2009) Child benefit. https://www.nav.no/en/home/benefits-and-services/relatert-informasjon/child-benefit.

32. Gunasekara FI, Richardson K, Carter K, Blakely T (2014) Fixed effects analysis of repeated measures data. International Journal of Epidemiology 43 (1):264-269. https://doi.org/10.1093/ije/dyt221

33. Allison PD (2009) Fixed Effects Regression Models. https://doi.org/10.4135/9781412993869

34. Luciano A, Meara E (2014) Employment Status of People With Mental Illness: National Survey Data From 2009 and 2010. Psychiatric Services 65 (10):1201-1209. https://doi.org/10.1176/appi.ps.201300335

35. NAV (2011) Disability benefit. https://www.nav.no/en/home/benefits-and-services/relatert-informasjon/disability-benefit.

36. Statistics Norway (2020) Immigrations, by reason for immigration, first citizenship and year of immigration 1990 - 2019. https://www.ssb.no/en/statbank/table/07113.

37. Close C, Kouvonen A, Bosqui T, Patel K, O’Reilly D, Donnelly M (2016) The mental health and wellbeing of first generation migrants: a systematic-narrative review of reviews. Globalization and Health 12 (1):47. 10.1186/s12992-016-0187-3

38. Stevens GWJM, Vollebergh WAM (2008) Mental health in migrant children. Journal of Child Psychology and Psychiatry 49 (3):276-294. https://doi.org/10.1111/j.1469-7610.2007.01848.x

39. Virupaksha H, Kumar A, Nirmala B (2014) Migration and mental health: An interface. Journal of Natural Science, Biology and Medicine 5 (2):233-239. https://doi.org/10.4103/0976-9668.136141

40. Øverland S (2016) Unemployment and mental health. Occupational and Environmental Medicine 73 (11):717-718. https://doi.org/10.1136/oemed-2016103831

41. Norwegian Directorate of Health (2019) Activity data for specialist mental health services for children and adolescents 2018 [Aktivitetsdata for psykisk helsevern for barn og unge 2018]. vol Report IS-2820. Norwegian Directorate of Health., Trondheim

42. Mossakowski KN (2008) Dissecting the Influence of Race, Ethnicity, and Socioeconomic Status on Mental Health in Young Adulthood. Research on Aging 30 (6):649-671. https://doi.org/10.1177/0164027508322693

\section{Figures}




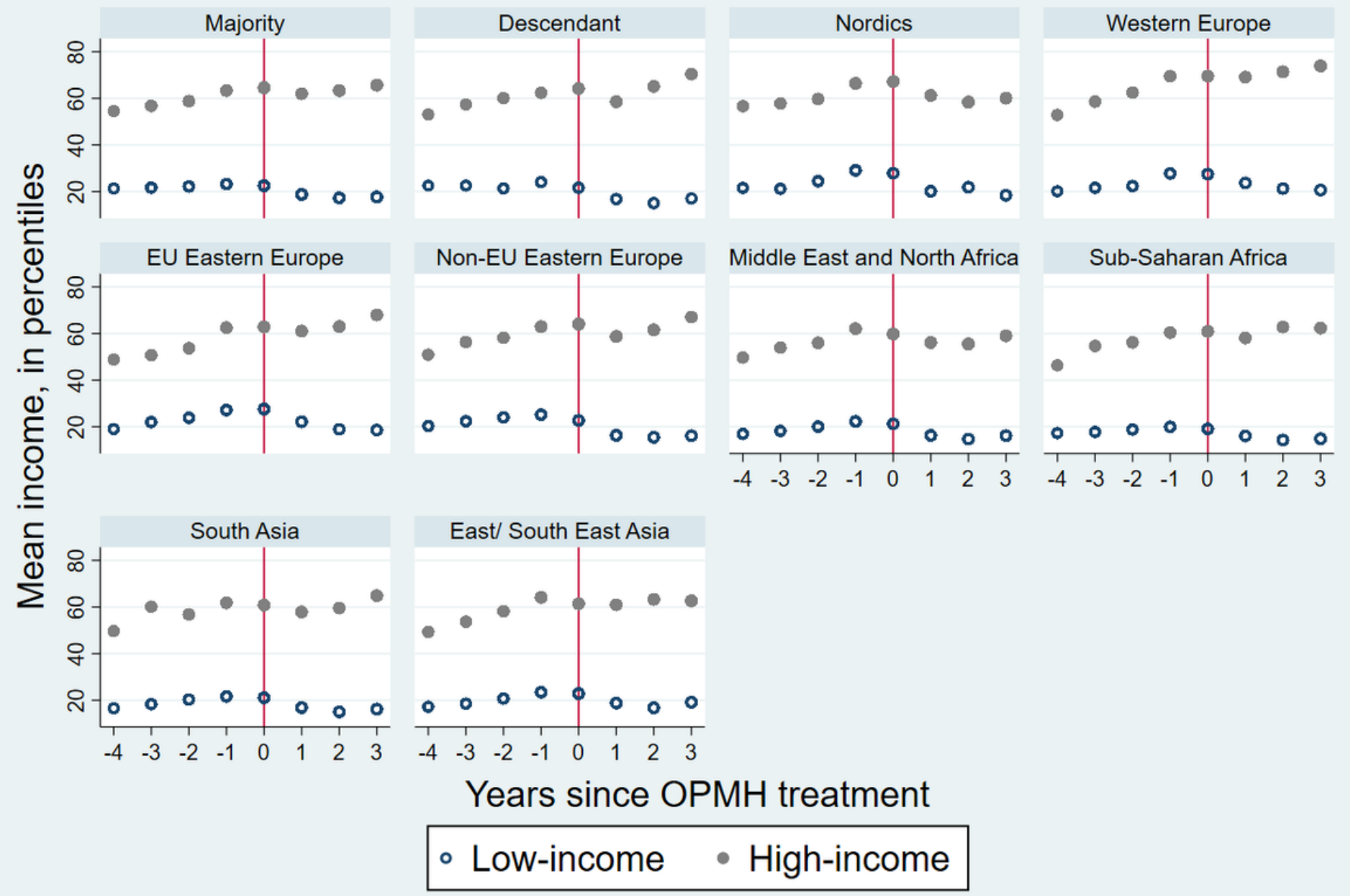

Graphs by migrant background, age adjusted

\section{Figure 1}

Age adjusted mean income for women with OPMH treatment in the years prior to and after treatment. Graphs by migrant background and income group.

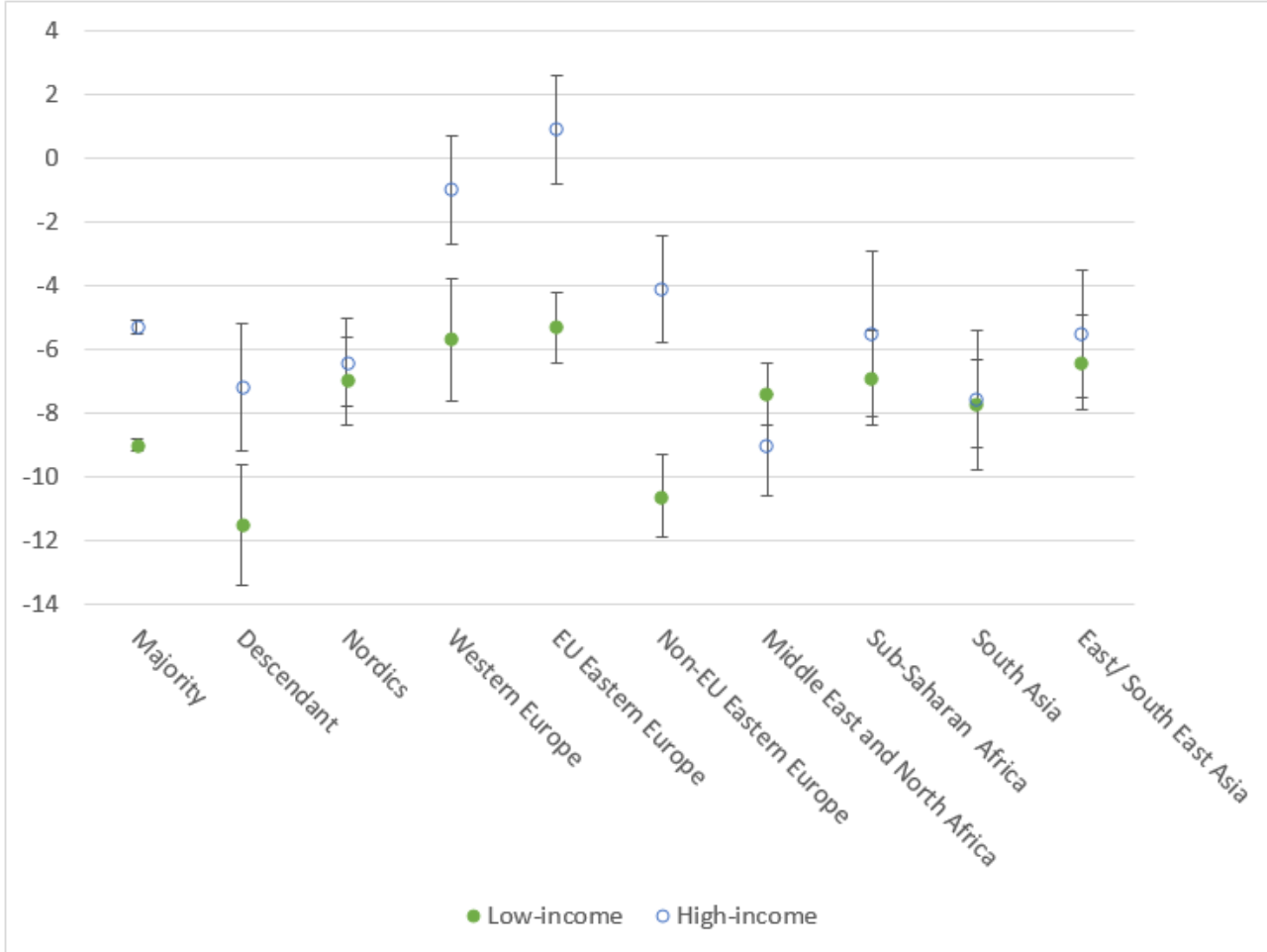


Figure 2

The interaction effect of OPMH service use on income by region of origin and income distribution. Adjusted for age, educational level, marital status, motherhood and time fixed effects. 